\title{
Evaluating Student Design Activity in Engineering Design Projects
}

\author{
D.S. Petkau, P.Eng. \\ Department of Biosystems Engineering \\ University of Manitoba \\ Winnipeg, MB R3T 5V6 \\ (petkau@cc.umanitoba.ca) \\ D.D. Mann, P.Eng. \\ Department of Biosystems Engineering \\ University of Manitoba \\ Winnipeg, MB R3T 5V6 \\ (Danny_Mann@ms.umanitoba.ca)
}

\begin{abstract}
Student design projects in engineering courses are usually short term conceptual design problems. Upon completion of the projects it is difficult to assess which design activities had the greatest contribution to the success of the design. In the fall of 2006, students in 2nd, 3rd, and 4th year Design Trilogy courses at the University of Manitoba were asked to keep extensive design journals. Design teams consisted of multiyear students completing various industry projects. Student design activities recorded in the journals were coded. Data were compared between design teams and between students in the different years of study. This paper describes the evaluation process and reports on the preliminary findings.
\end{abstract}

\section{Introduction}

Design has always been an important part of the engineering process. Design procedures vary with the individual and the type of project undertaken. Attempts have been made to define the engineering design process with limited success. There are many examples of design procedures available, that are used in industry and in our schools. These procedures explain the tasks needed to undertake a design activity but do not describe how to assure a successful design. This lack of understanding of the design process makes it difficult for engineers to describe exactly how they design and thereby difficult to teach design to students.
It has been described by Koen that the engineering method consists of the "state of the art" and heuristics [1]. These are ideas and principles that are learned through experience and built upon over time. Therefore for engineers to be successful they must understand their successes and be able to build upon the knowledge that they (and others) have obtained. One important method to maintain this knowledge is to keep accurate records. These detailed records of design activities, within a journal, could be related to the success of the completed design. Over time, information would be obtained as to how the design activities contribute to design success.

It could then be seen as valuable to train aspiring engineering students in the art of keeping an appropriate design journal. This along with the CEAB accreditation rules [2], which currently have a greater emphasis on the teaching of the design process, indicate the importance of design exercises in an engineering capstone course.

This paper is a preliminary examination of a first attempt to understand the relationship of engineering students design activities to the success of a completed design project. We updated the students journal assignment to encourage accurate and detailed activity records. Previous journal assignments were poorly defined and rarely completed correctly. We hope to understand how students complete a design project and the corresponding journal. Our understanding of the student process should lead to a system in which students will not only perform to a higher standard, but also understand the value of the exercise. 


\section{Course Background}

The Biosystems Engineering Department at the University of Manitoba, as in many engineering programs, has a capstone program in design as part of the completion of the degree program. The basic capstone program consists of three design courses taught over a three year period. The program is referred to as "Design Trilogy " details of which can be reviewed in the following publications [3],[4]. As a way to improve the ability to teach design and to improve the program, new techniques are implemented on a regular basis.

In this past year it was decided to enhance the journal assignment to help teach the students the value of communication and record keeping. In previous years the students were required to submit journals at the end of term for a total of $5 \%$ of their final grade. These journals were found to be lacking in detail and served no purpose to the students other than an assignment. It was felt that students would see the journals as just another assignment with no merit to their future careers as engineers.

In order to bring relevance to the journals for the students and to better understand how students design, it was decided to change the way we looked at the journal assignment. The problems with the old journal assignment were; lack of clear direction, lack of understanding of importance of concept, lack of sufficient grading weight, and lack of marking follow-up.

\section{Project Background}

In the fall 2006 term students were given a brief lecture and handout on journal material. They were given materials to use as journals and a marking rubric. All students were expected to hand journals in on a weekly basis. Journals were marked four times during the term. Marks were assigned for each student once in each third of the course. The weeks that each student's journal was marked was chosen at random and the student only found out after receiving a mark. The journals were also marked at the end of term. A total of $10 \%$ of the final mark was assigned to the journal. All marking of the journals was based on the marking rubric in Table 1 based on work by Sobek [5].
Table 1: Design Journal Evaluation Form

\begin{tabular}{|c|c|c|c|c|}
\hline $\begin{array}{l}\text { Form Point } \\
\text { Values: }\end{array}$ & 0 & 1 & 2 & 3 \\
\hline $\begin{array}{l}\text { Date/Time } \\
\text { /Attendees }\end{array}$ & Never & $\begin{array}{c}\text { Some- } \\
\text { times }\end{array}$ & Mostly & Always \\
\hline \multicolumn{5}{|l|}{ Labelling } \\
\hline $\begin{array}{l}\text { Content } \\
\text { Point } \\
\text { Values: } \\
\end{array}$ & 0 & 2 & 4 & 6 \\
\hline \multirow{2}{*}{$\begin{array}{l}\text { Regular } \\
\text { Document- } \\
\text { ation }\end{array}$} & Nothing & $\begin{array}{l}\text { Large } \\
\text { Gaps }\end{array}$ & $\begin{array}{l}\text { Most days } \\
\text { accounted }\end{array}$ & $\begin{array}{c}\text { All Time } \\
\text { Accounted }\end{array}$ \\
\hline & & & & \\
\hline $\begin{array}{l}\text { Thorough- } \\
\text { ness }\end{array}$ & $\begin{array}{c}\text { Almost } \\
\text { Nothing } \\
\end{array}$ & Sketchy & $\begin{array}{c}\text { Fairly } \\
\text { Thorough }\end{array}$ & $\begin{array}{c}\text { Very } \\
\text { Thorough }\end{array}$ \\
\hline $\begin{array}{l}\text { Insight } \\
\text { Point } \\
\text { Values: }\end{array}$ & 0 & 2 & 4 & 6 \\
\hline Insight & $\begin{array}{l}\text { Almost } \\
\text { Nothing }\end{array}$ & Sketchy & $\begin{array}{c}\text { Fairly } \\
\text { Thorough }\end{array}$ & $\begin{array}{c}\text { Very } \\
\text { Thorough }\end{array}$ \\
\hline Totals: & & & & \\
\hline & & & Grand Total: & \\
\hline
\end{tabular}

Once the term was complete a research project was undertaken to study the information in the student's journals and how it related to their design projects. A number of aspects were considered. Since in this term the projects were undertaken as multiyear projects there was an opportunity to study; what tasks each level of student undertook, how well the students completed their journals, how the design activities in the journals related to the success of the design project, and what design activities were undertaken to complete the design.

\section{Coding Scheme and Development}

Once signed approval for use of their journals was obtained from the individual students a method of coding the information needed to be developed. It was decided to use as a basis the work of Sobek [6] in developing a coding rubric. These codes are summarized in Table 2. A decision was made that it was necessary to use one level of design as the project work of our students only involved the concept stage. This level is the initial stage of a design project and considered to be the high level of abstraction. All four types of design activity were considered in order to capture the engineering design process. It was decided to expand the definition of project management to include a greater range of the communication activities as expected from our students. 
Table 2: Design Activities Codes and Definitions

\begin{tabular}{|c|c|}
\hline $\begin{array}{l}\text { Problem } \\
\text { Definition (PD) }\end{array}$ & $\begin{array}{ll}- & \text { identifying customer needs } \\
- & \text { establishing target specifications } \\
- & \text { concept generation } \\
- & \text { concept selection } \\
- & \text { concept testing } \\
- & \text { patent searching } \\
- & \text { benchmarking of competition } \\
- & \text { reverse engineering an existing design }\end{array}$ \\
\hline $\begin{array}{l}\text { Idea } \\
\text { Generation (IG) }\end{array}$ & $\begin{array}{ll}\text { - } & \text { brainstorming } \\
\text { - } & \text { listing alternatives (ideas) } \\
\text { - } & \text { looking for ideas via internet, patents, } \\
\text { - } & \text { etc. (ie. What's out there) } \\
\text { - } & \text { recording "breakthrough" ideas } \\
\text { - } & \text { "how if.......?" } \\
\text { - } \quad \text { using CADout.....?" } \\
\quad \rightarrow \text { preliminary design models to better } \\
\text { communicate an idea }\end{array}$ \\
\hline $\begin{array}{l}\text { Engineering } \\
\text { Analysis (EA) }\end{array}$ & $\begin{array}{ll}\text { - } & \text { mathematical modeling } \\
\text { - } & \text { using decision matrices } \\
\text { - } & \text { listing pros/cons of ideas } \\
& \text { examining a design with analytical } \\
\text { - } & \text { diagrams } \\
\text { - } & \text { graphical modeling for: } \\
& \text { interference testing } \\
& \text { - dimensional analysis } \\
& \text { calculating density, volume, etc }\end{array}$ \\
\hline $\begin{array}{l}\text { Design } \\
\text { Refinement } \\
\text { (DR) }\end{array}$ & $\begin{array}{ll} & \begin{array}{l}\text { drawing completed sketches of a design } \\
\text { (including tolerances, dimensions etc.) }\end{array} \\
- & \begin{array}{l}\text { studying a design to determine } \\
\text { functionality }\end{array} \\
- & \text { changing existing features } \\
- & \text { adjusting/refining specifications } \\
- & \text { troubleshooting of design } \\
- & \text { using CAD, PROE, Solid Works for: } \\
& \quad \quad \text { detailed modeling }\end{array}$ \\
\hline $\begin{array}{l}\text { Internal } \\
\text { Communication } \\
\text { (IC) }\end{array}$ & $\begin{array}{ll}- & \text { scheduling } \\
- & \text { team meetings } \\
- & \text { identifying tasks } \\
- & \text { reporting project status } \\
\text { - } & \text { mentor meetings }\end{array}$ \\
\hline $\begin{array}{l}\text { External } \\
\text { Communication } \\
\text { (EC) }\end{array}$ & $\begin{array}{ll}\text { - } & \text { interim and final report writing } \\
\text { final presentation preparation and } \\
\text { - } & \text { delivery } \\
\text { - } & \text { client communication } \\
\end{array}$ \\
\hline
\end{tabular}

There were a total of 65 students in the Design Trilogy course in the fall of 2006. These students were split between $2^{\text {nd }}, 3^{\text {rd }}$, and $4^{\text {th }}$ year. Teams were made up of 2 second year students, 1 third year student and 2 fourth year students. The teams were allowed to develop their own work strategy and team leaders. Instructors for the three courses acted as mentors for the teams. There were a total of 13 teams. There were 10 industry projects in total, therefore some of the teams were assigned to complete duplicate projects.

The projects varied in scope and therefore it was difficult to draw direct comparisons to the individual project activities. The goal was to understand which activities group members undertake to complete the design. The diversity on the projects helped to gather a broad range of opportunities for students to complete various design tasks.
The design journals were copied and sorted into design groups. Coding was undertaken by the first author in consecutive order by group. This enabled cross-referencing a journal to other group members when there was some doubt as to dates and times of particular tasks. Individuals tend to work in teams for many of the job tasks and therefore information in one journal may help to clarify unclear information in a team-mates journal.

The first author defined the coding based on work by Sobek [6]. Once the first few journals were completed it was felt that the students projects were basically restricted to the concept level. Projects consisted of defining the problem, coming up with some alternatives, choosing one of the alternatives, engineering analysis, design refinement, and completing the final report. There was almost no time spent on activities defined as system level and no detailed design. Therefore a decision was made to focus on the concept level.

Another change from the design rubric was in the non-design related activities. Sobek [6] defines these activities as project management and delivery. It was found that the students in the Design Trilogy course spent a large portion of their project time on communication activities and therefore these activities were added to our design rubric (Table 3 ).

Table 3: Design Journal Evaluation Form

\begin{tabular}{|l|l|l|l|}
\hline \multirow{2}{*}{} & \multicolumn{3}{|c|}{ Concept Design } \\
\cline { 2 - 4 } & $\begin{array}{c}\text { Early } \\
<\text { Oct 9 }\end{array}$ & $\begin{array}{c}\text { Mid term } \\
\text { Oct 10 to } \\
\text { Nov 6 }\end{array}$ & $\begin{array}{c}\text { Late } \\
\text { Nov 6 }\end{array}$ \\
\hline $\begin{array}{l}\text { Problem } \\
\text { Definition }\end{array}$ & & & \\
\hline $\begin{array}{l}\text { Idea } \\
\text { Generation }\end{array}$ & & & \\
\hline $\begin{array}{l}\text { Engineering } \\
\text { Analysis }\end{array}$ & & & \\
\hline $\begin{array}{l}\text { Design } \\
\text { Refinement }\end{array}$ & & & \\
\hline $\begin{array}{l}\text { Internal } \\
\text { Communication }\end{array}$ & & & \\
\hline $\begin{array}{l}\text { External } \\
\text { Communication }\end{array}$ & & & \\
\hline
\end{tabular}

This could be a result of the way the course has been designed. The course has been combined with a Technical Communications course to eliminate the need for students to take a stand alone Technical Communication course. Therefore the students are asked to complete numerous individual assignments to comply with communication requirements. A second reason for the focus on the communication aspect is that the final mark is heavily weighted 
towards the final report. Over the years the students have been encouraged to develop their presentation and reporting skills as these are important to the engineer. Anecdotal comments over the past 5 years would indicate that the students have greatly improved their presentation skills. This project is then the first stage of determining the procedure to improving the design skills of the students.

A last change to the design rubric was the evaluation of the journals over different time periods. It is expected that individual design activities are related to stages in the process. Our interest was to understand how students reacted to these time determinant activities and how they affected the final design.

Students were instructed to complete journals as work progressed and at least at the end of a work day. Information would include time, place and task undertaken.

\section{Results and discussion}

There were a total of 65 students in the three years of the Design Trilogy course. Initially all 65 journals were read to determine suitability to the study. Journals were rejected if they had missing periods of time, had no information, or were difficult to understand. A total of 40 journals were considered to be suitable to study.

The next step was to obtain signed consent from the students to use their journals in the study. We obtained consent from 30 students which formed the basis of the study. One of these 30 journals was eliminated after the first coding task. This journal had unusual times for the daily tasks. It seemed that the student misunderstood the guidelines and entered times that it took to record events in the journal. No single task throughout the term was recorded at a time greater than 15 minutes. Most tasks were only 5 minutes long. This journal was also the only one from that particular team and therefore was not vital to the study.

The researcher then went through the process of coding the journals. They were coded by only one person. Journals were organized by team so that the coding would be sequential by group. In this way any discrepancies would be more easily recognized. Each journal was studied and coded according to the rubric. After the coding was completed the researcher revisited the journals to verify that the process was consistent.

The majority of the students failed to record times of the activities in the first few weeks of the projects. This was overcome in a number of ways. The subsequent portions of the journal were studied which gave a routine for that particular student. The activity was studied and time was estimated based on work accomplished. Fellow team-mates journal were studied to correspond times for certain activities.

Once the coding was complete the information was evaluated with respect to overall design activity, communication activity versus design activity, design activity by year in program, and design activity per time period.

In total $53 \%$ of the total time spent on the design projects was spent on external communication activities (Figure 1). This includes a total of $45 \%$ of the total in the last segment of the course. This is interpreted to mean that students spent $45 \%$ of their time in the production of the final presentation and report.

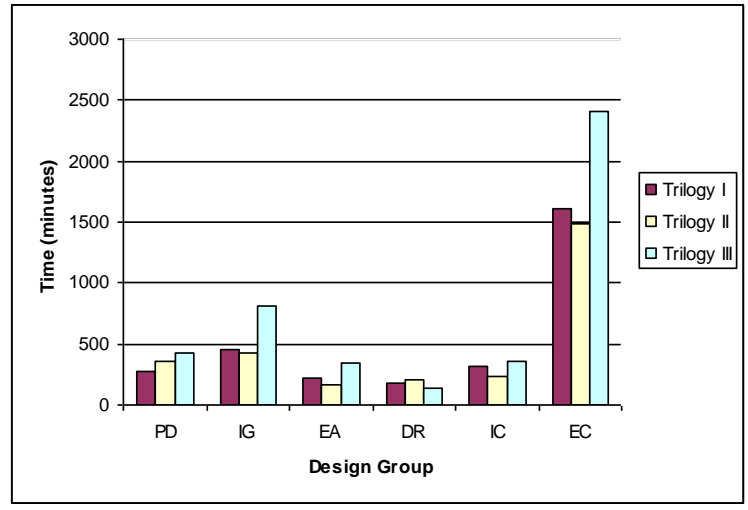

Figure 1. Design/Communication Activity (average per student)

A second observation is that the Design Trilogy III students spent an average of 75 hours on the projects while the Trilogy II and I students only spent an average of 50 hours on their projects (Figure 2). The actual percent of each students time spent on each design activity was fairly consistent. The difference was in the total time spent on the project.

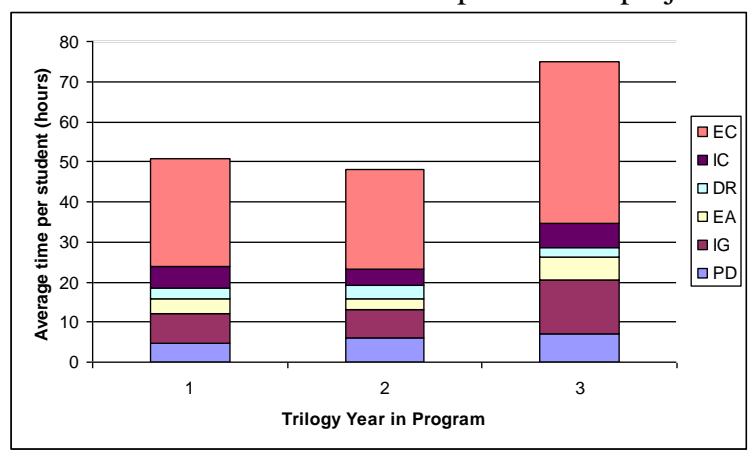

Figure 2. Design Activity by Year in Program (average per student) 
Another observation was that of the timing of the students design activities (Figure 3). As expected the students spent the early part of the course on problem definition and idea generation. The mid portion of the course was spent on some analysis and refinement. The late portion of the project was spent on external communication or the reporting of the results.

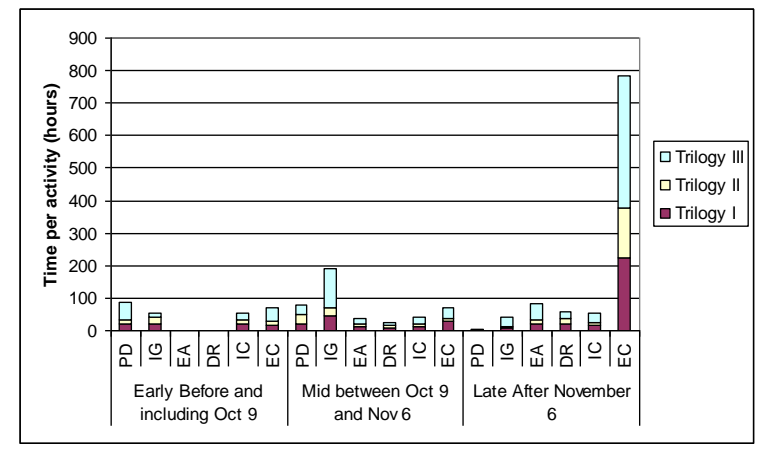

Figure 3. Total Hours Spent per Activity

A final observation is that the Trilogy III students spent a greater percent of their design time on idea generation and less time on design refinement than the students in the other two years. Students in Trilogy I and II spent a greater proportion of their time on routine engineering activities than the Trilogy III students. This would be attributed to the experience of the more senior students and their delegation abilities for the more routine tasks.

\section{Conclusion}

Initial expectations of this project were that students would better understand the responsibility and importance of design journals. We found that one third of the students still did not understand the basic principle of the journal to an extent that they would keep appropriate records. The remaining students keep acceptable records but even these students had gaps in the information they were recording. The information that was recorded was fairly easy to understand but was more related to administrative tasks than to real design information.

An important conclusion we reached was that the course is set up in a way that the students put more effort into reporting than into the actual design activities. This in understandable, as the reward (marks) is given for the presentation and the report to a greater extent than the success of the design.
We found that the set up of the course into multiyear teams, as described by Mann [7], was to the detriment of the students. We saw less delegation than expected and a corresponding greater workload for the Trilogy III students. A definite trend was to the more experienced students taking on the greater workload as they had less confidence in their team mates.

Further study will be to relate the success of the final designs to the design activities. We will also look at the teams as a unit and see if there are any trends in team workloads.

\section{References}

[1] B.V. Koen, "The Engineering Method and the State-of-the-Art", ASEE-IEEE Frontiers in Education Conference, Oct. 19-23, 1985, Golden, CO, pp. 247-251.

[2] http://www.engineerscanada.ca/e/files/report_ ceab .pdf

[3] D.D. Mann, K.J. Dick, D.S. Petkau, M.G. Britton, and S. Ingram. "Using mastery learning to teach the engineering design process". In Proceedings of the $2^{\text {nd }} C D E N$ Design Conference. Kananaskis, AB, July 17-20, 2005.

[4] D.D. Mann, S. Ingram, K.J. Dick, D.S. Petkau, and M.G. Britton. "Concurrent teaching of technical communication and the engineering design process". ASABE Paper No. 078003. Minneapolis, MN, June 17-20, 2007.

[5] D.K. Sobek, II, "Use of journals to evaluate student design processes". Proceedings of the 2002 American Society for Engineering Education Annual Conference \& Exposition. Montreal, QC, June 16-19, 2002.

[6] D.K. Sobek, II, "Preliminary findings from coding student design journals". Proceedings of the 2002 American Society for Engineering Education Annual Conference \& Exposition. Montreal, QC, June 16-19, 2002.

[7] D.D. Mann, K.J. Dick, D.S. Petkau, S. Ingram, "Experiences with inter-year capstone design teams". In Proceedings of the $4^{\text {th }}$ CDEN Design Conference. Winnipeg, MB, July 22-24, 2007. 